\title{
The protective and attractive covering of a vegetated embankment using coir geotextiles
}

\author{
S. Vishnudas ${ }^{1}$, H. H. G. Savenije ${ }^{1,2}$, P. Van der Zaag ${ }^{2,1}$, K. R. Anil ${ }^{3}$, and K. Balan ${ }^{4}$ \\ ${ }^{1}$ Water Resources Section, Delft University of Technology, Delft, The Netherlands \\ ${ }^{2}$ UNESCO-IHE, Delft, The Netherlands \\ ${ }^{3}$ College of Agriculture, Trivandrum, Kerala, India \\ ${ }^{4}$ Government College of Engineering, Thrissur, Kerala, India
}

Received: 15 August 2005 - Published in Hydrol. Earth Syst. Sci. Discuss.: 10 November 2005

Revised: 29 May 2006 - Accepted: 1 August 2006 - Published: 8 August 2006

\begin{abstract}
This paper presents the results of a field experiment conducted in Kerala, South India, to test the effectiveness of coir geotextiles for embankment protection. The results reveal that treatment with geotextile in combination with grass is an effective eco-hydrological measure to protect steep slopes from erosion. In the context of sustainable watershed management, coir is a cheap and locally available material that can be used to strengthen traditional earthen bunds or protect the banks of village ponds from erosion. Particularly in developing countries, where coir is abundantly available and textiles can be produced by small-scale industry, this is an attractive alternative for conventional methods. This paper analyses the performance of coir geotextile in different treatments with respect to soil moisture content, protection against erosion and biomass production.
\end{abstract}

\section{Introduction}

Soil erosion is increasingly recognized as a problem which needs an effective and economic solution. Several slope protection methods are currently used to stabilize slopes. Among these methods biotechnical methods, making use of natural vegetation are becoming more popular mainly for environmental and economic reasons. Natural vegetation on slopes is able to self-maintain, brake and dilute the kinetic energy of the rain and also provide surface roughness which slows the runoff velocity. The root system reinforces the soil and also facilitates infiltration of water by improving the porosity of the soil (Ranganathan, 1994; Ahn et al., 2002). However there are certain limitations which can hamper the establishment of vegetation: it is susceptible to drought, it is difficult to get established on slopes, it is unable to resist severe scour or high runoff and takes time to establish

Correspondence to: S. Vishnudas

(s.vishnudas@citg.tudelft.nl)
(Abramson et al., 1995). The effect of vegetation is only fully realised once it has reached maturity. During the critical stage of plant establishment the beneficial engineering properties of the vegetation may not be apparent and a site is still highly susceptible to soil erosion. Without immediate, appropriate and adequate protection, slopes can suffer from severe soil erosion and instability, which in turn makes vegetation establishment extremely difficult. Erosion of seeds and seedlings from unprotected sites by surface runoff and winds is costly since all previous attempts to establish vegetation on the slope have to be repeated (Rickson, 1995). Hence a protective covering on soil is required which resists soil erosion, retains runoff and facilitates establishment of vegetation on the surface. By protecting the surface, these covering materials dissipate the energy of raindrop impact, increase infiltration by reducing surface sealing and reduce the velocity of overland flow. In addition they help to reduce intense solar radiation, suppress extreme fluctuations of soil temperature, reduce water loss through evaporation and increase soil moisture, which can assist in creating ideal conditions for plant growth (Sutherland et al., 1998; Ziegler et al., 1997).

Over the past decade, geosynthetics have played a significant role in geo-environmental engineering applications. Woven and nonwoven geosynthetics have been used in various applications such as soil stabilization, turf reinforcement, erosion control, separation, filtration and drainage. Depending on the application, they are available under various trade names such as rolled erosion control systems (RECSs), geosynthetic matting, geotextiles, erosion control blankets (ECBs), erosion control re-vegetation mats (ECRMs) and turf reinforcement mats. Despite the technological advances made in this relatively new discipline, the majority of research has focused on geosynthetics made from synthetic materials. The use of naturally occurring fibre products for similar applications has not received significant consideration despite their potential (Ogbobe et al., 1998). However, strength properties of natural fibres are often superior

Published by Copernicus GmbH on behalf of the European Geosciences Union. 
Table 1. Manufacturing details of different types of coir. Geotextiles (adapted from Ayyar et al., 2002)

\begin{tabular}{lllllll}
\hline Designation & Type of warp yarn & $\begin{array}{l}\text { Approx. scorage } \\
\text { of warp yarn (No.) }\end{array}$ & Ends per dm & Type of weft yarn & Picks per dm & Mass $\left(\mathrm{kg} / \mathrm{m}^{2}\right)$ \\
\hline MMA1 & Anjengo & 14 & 9 & Vycome & 8 & 0.650 \\
MMA2 & Anjengo & 12 & 19 & Aratory & 11 & 1.400 \\
MMA3 & Anjengo & 12 & 11 & Aratory & 7 & 0.700 \\
MMA4 & Anjengo & 11 & 13 & Aratory & 7 & 0.900 \\
MMA5 & Anjengo & 11 & 18 & Anjengo & 9 & 1.300 \\
MMR1 & Aratory & 15 & 14 & Aratory & 14 & 0.875 \\
MMV1 & Vycome & 13 & 9 & Vycome & 8 & 0.740 \\
MMV2 & Vycome & 12 & 4 & Vycome & 4 & 0.400 \\
\hline
\end{tabular}

to synthetic fibres (Mandal, 1987). But there were only very few scientific literature available in field conditions in various applications using coir geotextile, and that has been cited in this paper.

Detention ponds are traditional water conservation structures used for drinking, domestic and irrigation purposes in Kerala, South India and they are the major water source for the village community. These ponds also act as an infiltration basin or recharge basin, which enhance groundwater recharge. In almost all micro-watersheds there is one village pond which is under the control of the local government called the Panchayat. During monsoon, the side banks of these ponds erode and the ponds get silted up. The same silt from the pond is subsequently used to restore the side banks but it is often eroded before vegetation can establish. Hence continuous maintenance is required for deepening and desilting of ponds to maintain their water holding capacity. Neither the local government nor the community may have enough funds for these labour intensive works. Ultimately the ponds get filled up and deteriorate and the area becomes subject to water shortage during the summer season and even in dry spells. Most watershed projects meant to support communities propose conventional stone bunds for soil and water conservation. However, the majority of the people cannot afford these structures without support from the government. Water storage capacity of the ponds is reduced due to erosion of side banks. This leads to water shortage in summer. Hence it is interesting to look for an alternative material which is effective in reducing soil erosion, enhancing soil moisture and vegetation growth, and which at the same time is economically attractive and can be manufactured locally.

The aim of the experiment was to study the effectiveness of coir geotextiles (natural fibre) for slope protection and to provide an alternative, cost effective option to reduce soil erosion, increase vegetation growth and increase soil moisture availability. If the efficacy of coir is proved, it can be used to strengthen watershed structures, thereby offering an attractive alternative for the expensive conventional methods. Although the processing of coir geotextile is labour intensive, this will provide a livelihood and an important source of food security for many farmers in Kerala, India.

\section{Background}

"Coir" is the agricultural fibre obtained from the husk of the coconut fruit which surrounds the base shell. It provides the raw material for the coir industry. Coir fibres are of different types and are classified according to varying degree of colour, length and thickness. Length of coir varies from $50 \mathrm{~mm}$ to $150 \mathrm{~mm}$ and diameters vary from $0.2 \mathrm{~mm}$ to $0.6 \mathrm{~mm}$. The fibre is of two types depending on the process of extraction: white fibre and brown fibre. White fibre is extracted after retting mature coconut husks for 9-12 months, followed by beating of the retted husks with mallet manually for thrashing out the coir pith. Brown fibre is extracted by mechanical means after soaking the husks for a short period in water. The brown fibre is relatively inferior in terms of quality. Brown coir is mainly used for ropes, rubberized coir and in upholstery. The extracted fibres are then spun into yarn of different weights. The yarn is classified in terms of type of fibre, colour (natural), twisting and spinning. The yarn is then converted into mats in handlooms, semi automatic looms or power looms. Scorage of yarn differs among different types of geotextiles. The scorage of the yarn is the number of strands that can be laid close to each other without overlapping in a length of $0.9 \mathrm{~m}$ (1 yard). Coir is a lignocelluloses polymeric fibre with $45 \%$ lignin and $43 \%$ cellulose. Coir fibres are less sensitive to UV radiations due to leaching out of photo-sensitive materials from its surface during the retting process. It has low tenacity (a unit used to measure the strength of a fibre or yarn, which is usually calculated by dividing the breaking force by the linear density (linear density in rope specification is weight/unit length) but the elongation is much higher (Ayyar et al, 2002). It is a natural biodegradable material with a highly crystalline structure with the spiral angle of the micro fibres ranging between 30$45^{\circ}$. This leads to a greater extensibility than in most other natural fibres. Its high lignin content contributes to higher 
durability and slow bio-degradation compared to other natural fibres (Balan and Rao, 1996). There are two types of coir mats (geotextiles) available: non-woven mats and woven mats. Non-woven mats are made from loose fibres, which are interlocked by needle punching or rubberizing. Woven mats are available in different mesh openings ranging from 3 to $25 \mathrm{~mm}$. A higher density means a tighter mesh and less open area. Over the years many varieties have been developed in India and are now commercially available in different mesh matting with international trade names such as: MMA1, MMV1, MMR1 etc., where MM stands for mesh matting and $\mathrm{A}, \mathrm{V}$ or $\mathrm{R}$ stands for the name of yarns based on the place of origin. Manufacturing details of different types of coir geotextiles are given in Table 1 .

Coir has the highest tensile strength of any natural fiber and retains much of its tensile strength when wet. It is also very long lasting, with infield service life of 4 to 10 years (English, 1997). The reason for the greater strength of coir is its high lignin content (Ayyar et.al, 2002). Because of its high tensile and wet strength, coir matting can be used in very high flow velocity conditions (English, 1997). Tests conducted by Schurholz (1991), cited in: Banerjee (2000), for material testing on jute, sisal, coir and cotton over a prolonged period of time in highly fertile soil maintained at high humidity (90\%) and moderate temperature revealed that coir retained $20 \%$ of its strength after one year whereas cotton degraded in six weeks and jute degraded in eight weeks. Rao and Balan (2000), in their erosion control study, showed that coir geotextile (MMA3 and MMV2) is capable to prevent surface erosion of particles along the surface of a slope and facilitates in sedimentation of soil on previously exposed rock surfaces. Even after seven months, the matting retained 56\% of its original strength against the reported value of $56 \%$ reduction in strength in six months by Oostbuizer and Kruger (1994), cited in Rao and Balan (2000). Anil and Sebastian (2003) in their study using coir geotextile (MMV1) on different slopes show that there is considerable reduction in soil erosion in the treatment plots. In the treatment plots with a slope of $20 \%$, soil conservation was 77 times higher compared to control plots; on a slopes of 30-40\% it was 17 times higher. Also there is considerable reduction in the time that it takes for the different treatments to achieve slope stabilisation. Plots with geotextiles stabilised earlier than control plots. Reduction in soil loss is mainly due to the coir matting, which reduces the raindrop impact as it intercepts the direct contact with soil. Balan (2003), in his study using coir geotextile (MMV1) for gully plugging in the high land region of Kerala shows that gullies on the upstream side have a siltation of $45 \mathrm{~cm}$ and on the downstream side a siltation of $10 \mathrm{~cm}$ after one monsoon season. Lekha (2004), in her field trial using coir geotextile (MMA3) for slope stabilisation, observed that after seven months of laying, coir retained $22 \%$ of the strength of a fresh sample. Also the reduction in soil erosion and increase in vegetation is significant in plots treated with geotextile. Thomson and Ingold (1986) through their study revealed that geotextiles can be used in combination with vegetation to provide a composite solution of soil erosion control.

Coir matting has an open area of 40 to 70 percent. Hence it allows the growth of grass and provides a large number of miniature porous check dams per square metre of soil. It slows down and catches runoff so that sediment settles and water either passes through the matting or percolates into the underlying soil. As geotextiles degrade, they provide mulch and conserve moisture for plant growth. On impact with an unprotected soil surface, raindrops loosen the soil particles, causing an incremental movement of the suspended particles down slope. Soils are susceptible to erosion by flowing water even at very low flow rates. If the energy of falling rain can be absorbed or dissipated by vegetation or some other soil cover or surface obstruction, the energy transfer to the soil particles will be reduced and hence soil erosion. When geotextiles are used, they absorb the impact and kinetic energy of raindrops and reduce surface runoff. Also seeds and vegetations are protected from being washed away (Anil, 2004).

\section{Study area}

The Amachal watershed in the Trivandrum District, in the Western Ghat region of Kerala, India, has been selected for an experiment to test the effectiveness of using coir geotextiles for bank stablisation. The watershed lies in the midland region between $8^{\circ} 28^{\prime} 57^{\prime \prime}$ and $8^{\circ} 29^{\prime} 44^{\prime \prime}$ north, $77^{\circ} 6^{\prime} 26^{\prime \prime}$ and $77^{\circ} 7^{\prime} 16^{\prime \prime}$ east. The watershed is characterized by moderately sloping to steep hills intervened by very gently sloping valleys. The area experiences a humid tropical climate with two distinct monsoons (Northeast and Southwest) and an average mean annual temperature of $26.50^{\circ} \mathrm{C}$. The relative humidity varied from 62 to 100 percent (GoK, 2002). The Southwest monsoon commences by the first week of June and continues up to September and the Northeast monsoon sets in by the middle of October and extends up to December. Annual rainfall amounts to $1500 \mathrm{~mm} /$ year. Peak rainfall in the experimental period was observed in the month of October (429 mm/month) followed by June ( $243 \mathrm{~mm} / \mathrm{month})$. Rainfall events are generally of high intensity and short duration especially in the Southwest monsoon. This rainfall typically is in the form of an evening shower with a clear sky during the day (GOK, 2002).

\section{The experiment}

\subsection{Materials}

Coir has been used in this experiment as a temporary erosion control measure to help in establishing vegetation and to stabilise steep slopes such as embankments of ponds. Coir matting selected for the study is MMV1 with the smallest mesh opening of $6 \times 6 \mathrm{~mm}^{2}$ and a density of $0.74 \mathrm{~kg} / \mathrm{m}^{2}$. The 


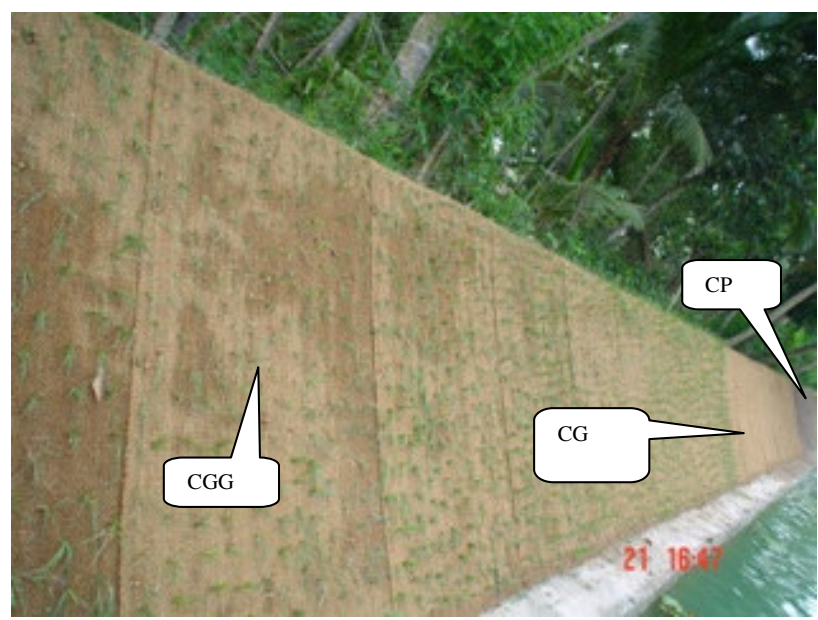

Fig. 1. Side of pond with different treatments.

tensile strength of fresh coir matting is $13.8 \mathrm{kN} / \mathrm{m}$. The selection of material was based on the steepness of the slopes. Literature shows that for higher slopes, geotextiles with small mesh openings are better to reduce soil erosion and absorb the impact of raindrops.

\subsection{Field layout and installation techniques}

A village pond in the watershed was selected for the field experiment. The side banks of this pond get eroded even during summer showers. The type of soil is silty sand. The capacity of the pond is $48 \mathrm{~m} \times 123 \mathrm{~m} \times 2.1 \mathrm{~m}$. The pond has a natural depression on one side (see Fig. 2a); the water level in the pond fluctuates from season to season. The slope of the embankment is $70^{\circ}$. The height of the exposed slope of the embankment is about $3 \mathrm{~m}$. The length of the embankment varies from $3.10 \mathrm{~m}$ to $3.50 \mathrm{~m}$. Erosion is caused by both rainfall and runoff. The limitation for providing a gentle slope to the embankment is that three sides of the pond are surrounded by existing village roads and the other side is a pedestrian road. Beyond the road on two sides, there are existing irrigation canal. Conventional method using rubble for the protection of the embankment is very expensive and hence they opt for the vegetative measures. Hence coir geotextile was applied as a protective material for stabilising the steep slopes. The experiment consists of three treatments (a) coir geotextile with planted grass (CGG), (b) Coir geotextile alone (CG) and (c) control plot (CP); replicated four times along the sides of the pond. Each side of the pond was divided in three equal parts for the three treatments. Figure 1 shows the side of pond with different treatments.

The coir was laid during 17-22 May 2004, just before the onset of the monsoon. The installation procedure followed was generally similar to that used for surface erosion control. All the vegetation was removed and the soil on the surface of the slope was well graded to remove unevenness, since any irregularity may allow water to flow under the matting and thus cause undercutting (Rao and Balan, 2000). Trenches of $30 \mathrm{~cm} \times 30 \mathrm{~cm}$ were dug at the top of the slope to anchor the geotextile. Rolls of the matting were first anchored in the top trench and then unrolled along the slope. Anchoring was done using bamboo pins cut to a length of $25-30 \mathrm{~cm}$, instead of iron hooks used conventionally. Pins were driven at right angles to the slope to anchor the matting. Each roll was given an overlap of a minimum of $15 \mathrm{~cm}$ and anchored firmly with bamboo pins spaced in a grid of $1 \mathrm{~m}$ spacing. Bamboo pins were also driven at the joints with a spacing of $1 \mathrm{~m}$. At the bottom, matting was rolled in two layers and anchored with bamboo pins to hold the soil eroded if any and also to reduce the intensity of runoff. In the conventional practise trenches were also dug at the bottom of the slope. After installation, matting was pressed to closely follow the soil surface. Trenches were backfilled and compacted.

\subsection{Planting of grass}

The common grass species Axonopus compressus was selected for the study. This species is used as fodder in this watershed. It was planted in the treatment plots at a spacing of $10 \mathrm{~cm}$.

\section{Monitoring}

Rainfall was measured using a self-recording rain gauge installed in the field. Soil moisture, vegetation, nutrient loss and bio-degradation of coir were measured from all the three treatments directly. The experiment was conducted and monitored with close involvement of the user community. In this study the user community themselves developed indicators for monitoring and evaluation. They scored monitored and evaluated the results.

Through joint experimentation with the people, beneficiaries received training and experience in the design, implementation and evaluation of experiments. In this way their capacity for innovation can be substantially increased (Johnson et al., 2003). Bunch and Lopez (1999), through their study reveal that, for farmers to accept soil conservation technologies, the technology should enhance yields. It is the increase in yield that convinces the farmers of the value of soil conservation. If the yields have increased or costs have decreased, artificial incentives are not required. On the other hand if yields have not increased, no artificial incentive will make the adoption of the technology sustainable. Hence sixty people living in the vicinity of the pond were selected to monitor and evaluate the performance of the different treatments. They monitored the density and uniformity of the established vegetation, and the soil erosion from the upper and lower portion. Data sheets were provided for scoring. Figures $2 \mathrm{a}$ and $\mathrm{b}$ shows the pond before and after the treatment. 


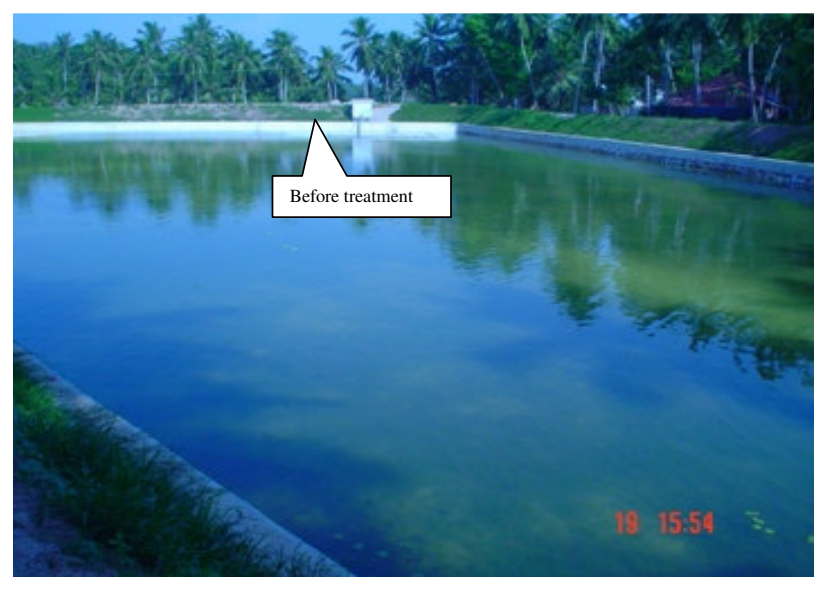

Fig. 2a. Pond before treatment.

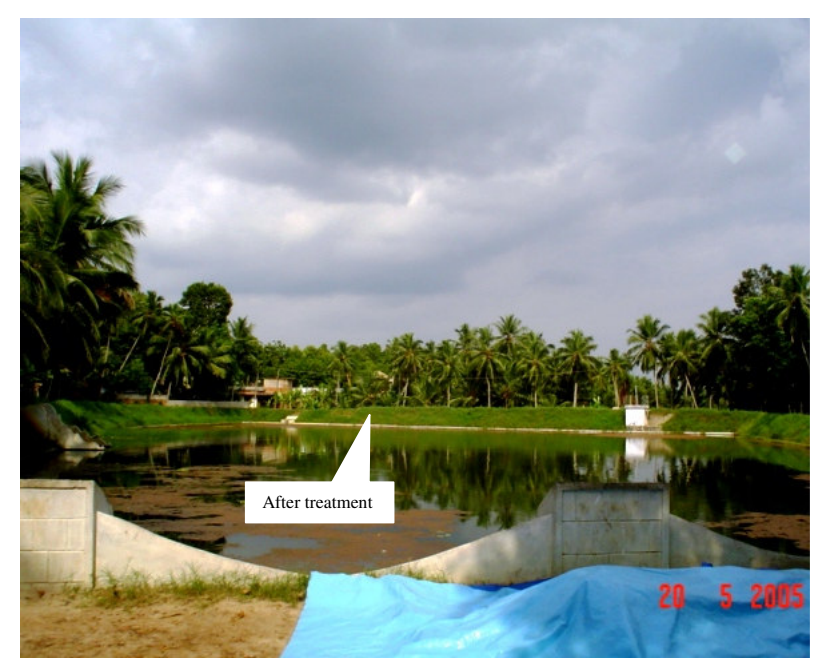

Fig. 2b. Pond after treatment.

\section{Results and discussions}

\subsection{Soil moisture}

Soil moisture was determined by gravimetric method from different treatment plots. Soil samples from the root zone were collected monthly and its initial weight was recorded $\left(\mathrm{w}_{1}\right)$. Subsequently samples were dried in sunlight until a constant weight was obtained, which was considered as the oven-dry weight $\left(\mathrm{w}_{2}\right)$. Variation in soil moisture in different treatments with respect to rainfall is presented in Fig. 3. Soil moisture was found to be declining subsequently during the observation period even with the increase in rainfall events $(40-120 \mathrm{~mm} /$ day $)$ in the month of October; due to the peculiarity of the Southwest monsoon. Soil moisture in CGG is $21 \%$ higher than in the control plot during the dry period. In CG, soil moisture is less than in CGG. This is be-

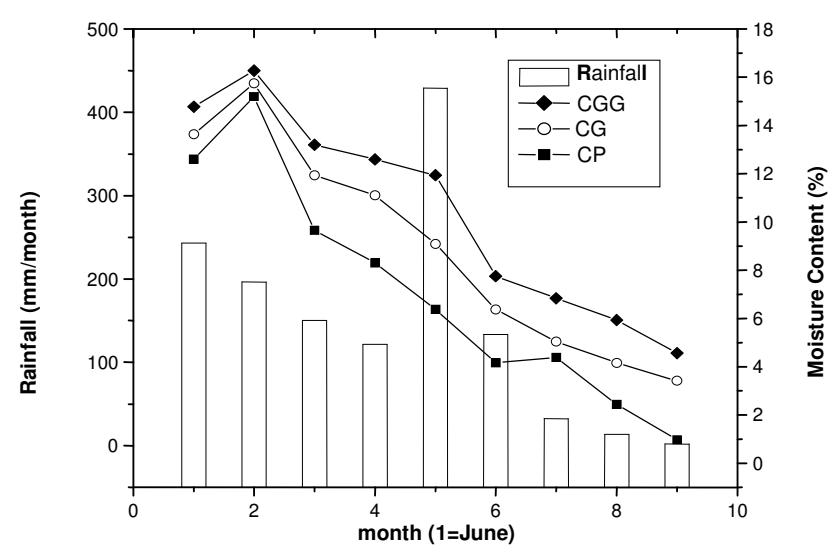

Fig. 3. Variation in moisture content with respect to rainfall.

cause in CGG, Axonopus compressus is well established as a canopy reducing solar radiation. Whereas in CG, the area was invaded with the same natural vegetation as in the control plot and most of this vegetation consists of shrubs and broad-leaved plants. These plants dried up from December onwards, and less moisture was retained than in CGG. In CP, the density and uniformity of vegetation was much less along with the occurrence of soil erosion and runoff. Hence moisture retention was least in these plots. Soil moisture retained during the dry period in CGG, CG and CP experiments are in the ratio 1: $0.75: 0.21$.

\subsection{Protective covering}

As the pond is used by the community for both domestic purposes and irrigation, a participatory approach was adopted to measure soil erosion. People living near the pond were selected and data sheets were provided monthly to compare the erosion in the different plots. The response of the participants shows that the erosion in the treated plots is significantly less compared to the control plot. It varied in response to the rainfall. Treatment with CGG stabilised first followed by CG. The control plot did not stabilise during the monitoring period.

Figure 4 shows the mean and standard deviation of the scores given by the participants with respect to soil erosion in the different plots. People could give a score from 10-50, where 50 represent maximum reduction in soil erosion. In the plots with CGG, scoring lies in the range of 40-50 and in CG the scoring ranges from 30-40. The graph clearly shows that an immediate effect was seen in plots treated with geotextiles. It can be seen that there was some erosion in the plot treated with CG alone during the initial stage, but that thereafter erosion decreased with the growth of vegetation. Both CGG and CG stabilised within nine months. Whereas erosion persisted in the control plot. 


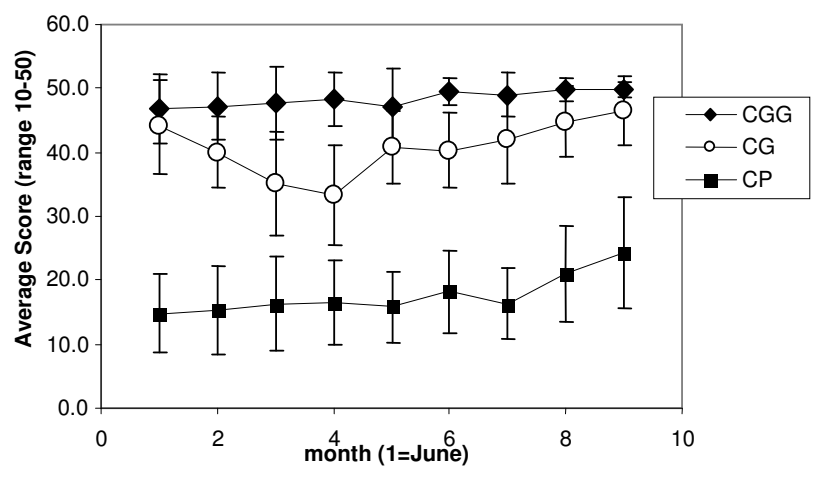

Fig. 4. Soil Erosion, people's response.

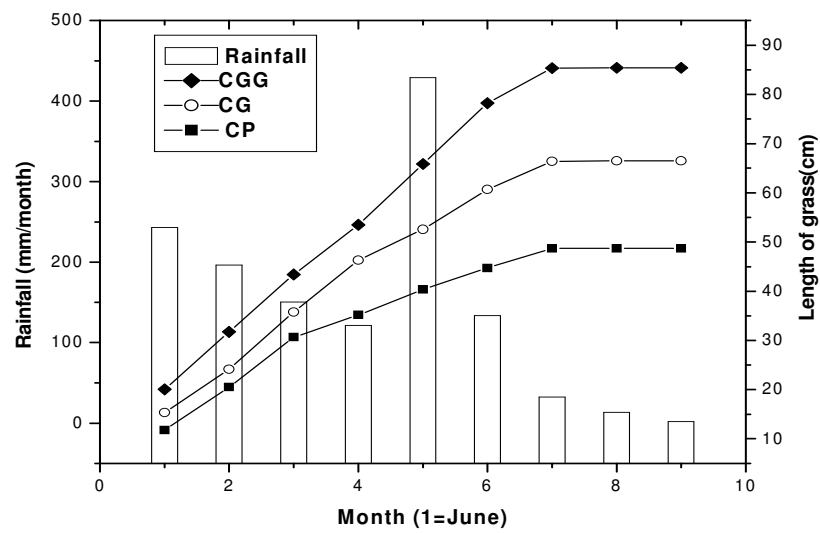

Fig. 5. Length of grass (measured).

\subsection{Vegetation}

Coir matting installed to cover the soil surface provides ample opportunity for the growth of vegetation. Even degraded geotextile contributes to the organic composition of the soil and promotes vegetation. Length of grass, weed intensity, uniformity and density of grass has been considered as measures for vegetation growth. Within nine months, vegetation was well established and the slope was stabilised in the area covered with geotextiles. Average length of the grass of the same species as that in CGG is being measured from all the plots to compare the length of grass.

Figure 5 shows the variation in height of the vegetation at all plots. Growth of vegetation in CGG shows greater values than in CG. The control plot shows the lowest value. In CGG, vegetation established well before it started at CG and $\mathrm{CP}$. In CG and CP, vegetation established with different varieties of weeds, whereas in CGG only Axonopus compressus was grown. This vegetation started drying up in December and even at that time the control plots were not stabilised. Intensity of plants per $\mathrm{m}^{2}$ was identified from June 2004 to February 2005. Among the grasses Axonopus compressus and Heteropogon contortus alone survived after December.
Table 2. ANNOVA table; response of participants on length of grass, whole treatment

\begin{tabular}{llllllllll}
\hline & B1 & B2 & B3 & B4 & B5 & B6 & B7 & B8 & B9 \\
\hline C1A1 & 32 & 35 & 42 & 45 & 47 & 46 & 44 & 42 & 36 \\
C1A2 & 21 & 25 & 30 & 30 & 33 & 35 & 36 & 29 & 31 \\
C1A3 & 13 & 20 & 22 & 20 & 23 & 19 & 17 & 18 & 28 \\
C2A1 & 44 & 45 & 44 & 47 & 48 & 48 & 45 & 43 & 42 \\
C2A2 & 39 & 41 & 32 & 34 & 35 & 30 & 21 & 25 & 28 \\
C2A3 & 19 & 28 & 23 & 19 & 19 & 15 & 15 & 14 & 19 \\
C3A1 & 46 & 47 & 49 & 49 & 48 & 49 & 48 & 46 & 43 \\
C3A2 & 42 & 32 & 34 & 34 & 31 & 27 & 24 & 21 & 28 \\
C3A3 & 30 & 30 & 21 & 18 & 19 & 18 & 15 & 16 & 19 \\
C4A1 & 45 & 46 & 46 & 44 & 50 & 47 & 47 & 46 & 44 \\
C4A2 & 31 & 29 & 26 & 21 & 24 & 19 & 18 & 23 & 24 \\
C4A3 & 23 & 22 & 21 & 20 & 20 & 18 & 18 & 16 & 19 \\
\hline
\end{tabular}

$\mathrm{F}=10.8$

A- Treatment, $\mathrm{A} 1=\mathrm{CGG}, \mathrm{A} 2=\mathrm{CG}, \mathrm{A} 3=\mathrm{CP}$ respectively, $\mathrm{C}$ - Sides of the pond, $\mathrm{C} 1=$ North , B- Month, $(1=$ June $)$

Maximum intensity was found to be of Axonopus compressus.

The average length of the sampled leaves, at any period, is assumed to be indicative of the vegetation growth at that period. The perception of the people has been statistically analysed by 3 factor ANOVA ${ }^{1}$. The ANOVA table for the perceived length of the grass is shown in Table 2 (qualitative data).

In the CGG (A1) experiment, the length of the grass generally increased over the first four-five months. Minimum response on length of grass was noted in the initial months, and gradually it increased until the month of November. The monitoring was carried out for 9 months from June, with 3 treatments on 4 areas. Hence the degree of freedom $(\mathrm{df})=48$ $(8 \times 2 \times 3)$. The criterion for $5 \%$ significance is an $\mathrm{F}^{2}$ value of 1.4 and for $1 \%$ significance, the $\mathrm{F}$ value is 1.6 . In this study the $\mathrm{F}$ value $=10.8$, which shows that there is highly significant difference between treatments. Among the three different treatments significant increase in length of grass was observed in geotextile with grass plots compared to control plots.

Considering individual treatments, with $\mathrm{df}=2$, the criterion for $5 \%$ significance is $\mathrm{F}=3$ and for $1 \%$ significance, $\mathrm{F}$ $=4.6$. In this study the F value is 1321 , which shows that the treatments are very effective and differences between treatments are highly significant. The mean value for treatment A1 (CGG) is 44, for A2 (CG) is 28 and A3 (CP) is 19. The difference between $\mathrm{A} 1$ (CGG) and $\mathrm{A} 2(\mathrm{CG})$ is 15 and between $\mathrm{A} 2(\mathrm{CG})$ and $\mathrm{A} 3(\mathrm{CP})$ is 9 , whereas between $\mathrm{A} 1$

\footnotetext{
${ }^{1}$ ANOVA is a procedure to test for the difference in variability among treatments and between treatments.

${ }^{2} \mathrm{~F}$ value is the ratio of the variance between groups to the variance within groups.
} 


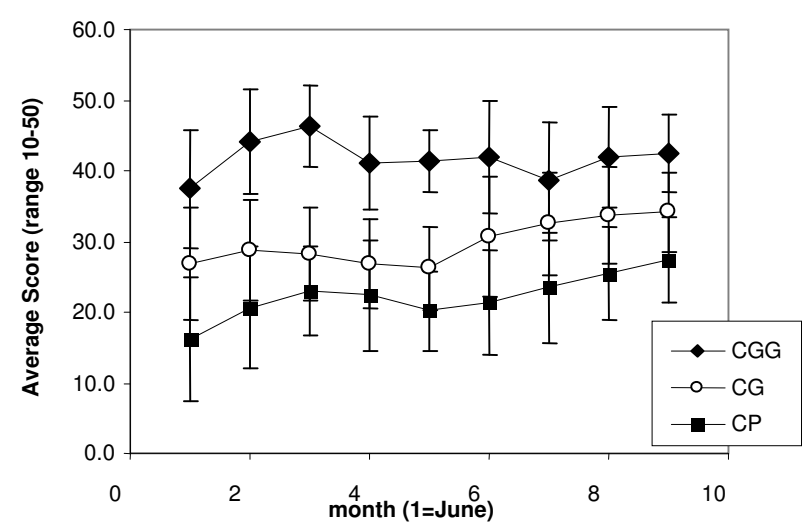

Fig. 6. Uniformity of grass, people's response.

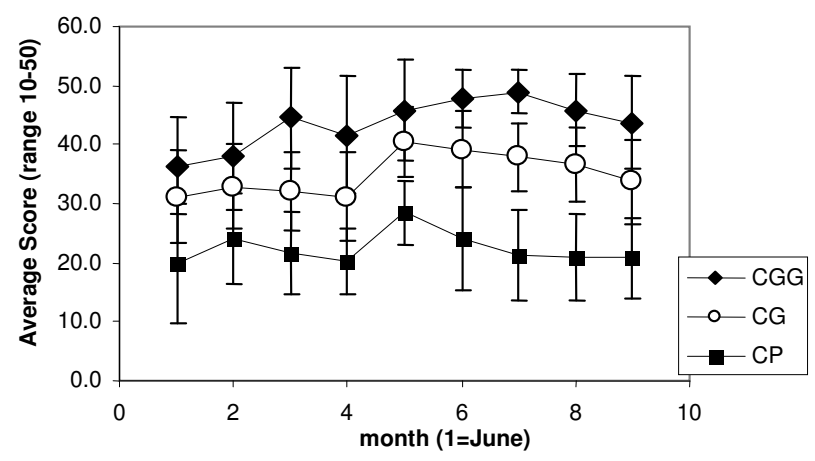

Fig. 7. Density of grass, people's response.

(CGG) and A3 (CP) is 24, while the critical difference $\mathrm{CD}^{3}$ $=0.9$. This shows that treatment $\mathrm{A} 1$ (CGG) is significantly different from A3 (CP), and A1 (CGG) and A2 (CG) are significantly different from $\mathrm{A} 3(\mathrm{CP})$. This shows that variations in the height of vegetation in the three treatments were similar in both qualitative and quantitative analysis. Response of the community with respect to the three treatments in terms of uniformity and density are shown in Fig. 6 and Fig. 7 respectively. Figures 8-11 show the photographs of the plots under different treatments.

\subsection{Biodegradation of coir}

Biodegradation of coir was studied based on ultimate tensile strength of the matting collected from the field during the period. The tensile strength test is carried out using the widewidth strip tensile test for geotextiles, a uniaxial tensile test in which the entire width of a $200 \mathrm{~mm}$ wide specimen is gripped in the clamps and the gage length is $100 \mathrm{~mm}$ (ASTM standard D 4595-86).

\footnotetext{
${ }^{3}$ Critical Difference (CD) is the minimum difference between a pair of means to be significantly different from each other.
}

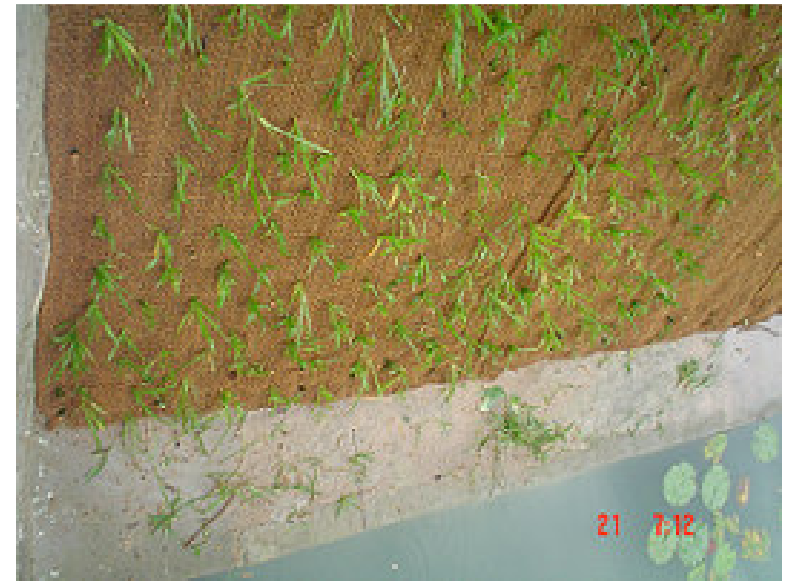

Fig. 8. CGG, third day of installation.

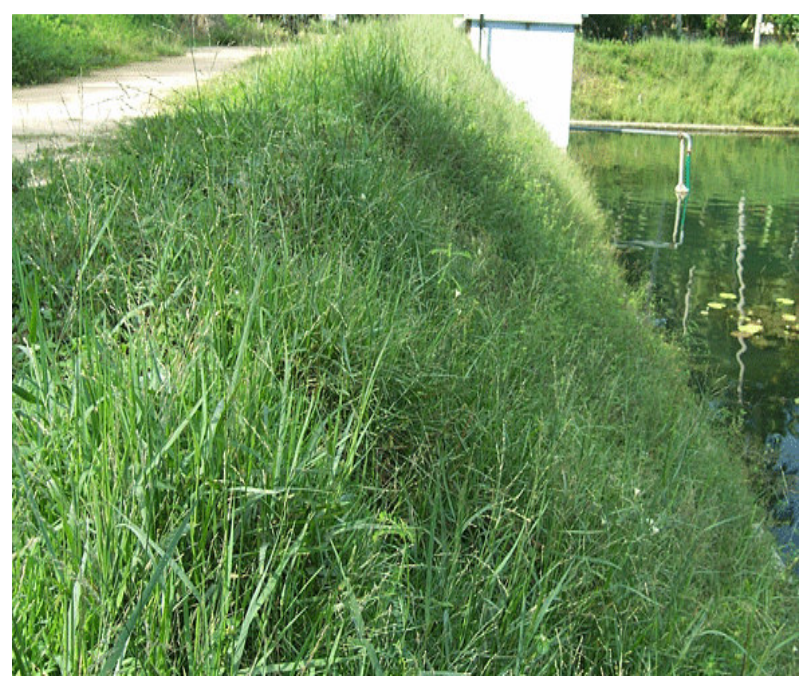

Fig. 9. CGG thick vegetation after 7 months.

Figure 12 shows the degradation curve of the geotextile with respect to time. The coir retained 19\% of the strength of a fresh sample after 9 months. After 7 months, it was observed that tensile strength of geotextiles was reduced by about $70 \%$. By that time a sustainable erosion control measure by the establishment of vegetation was observed in the CGG and CG plots whereas erosion persisted in the control plots. Hence the increase in the rate of degradation during the period did not affect the effectiveness of coir geotextiles as an erosion control measure. 


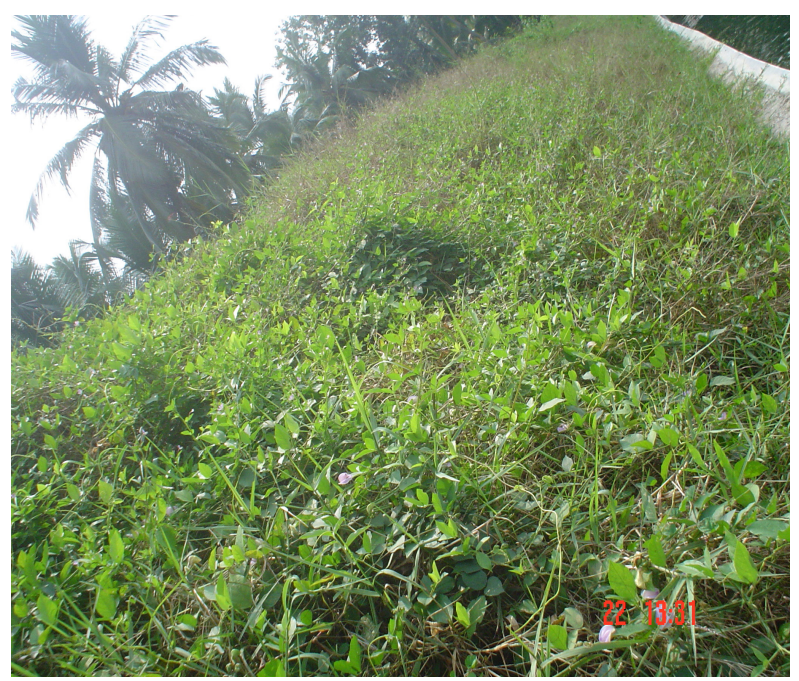

Fig. 10. CG, natural vegetation after 7 months.

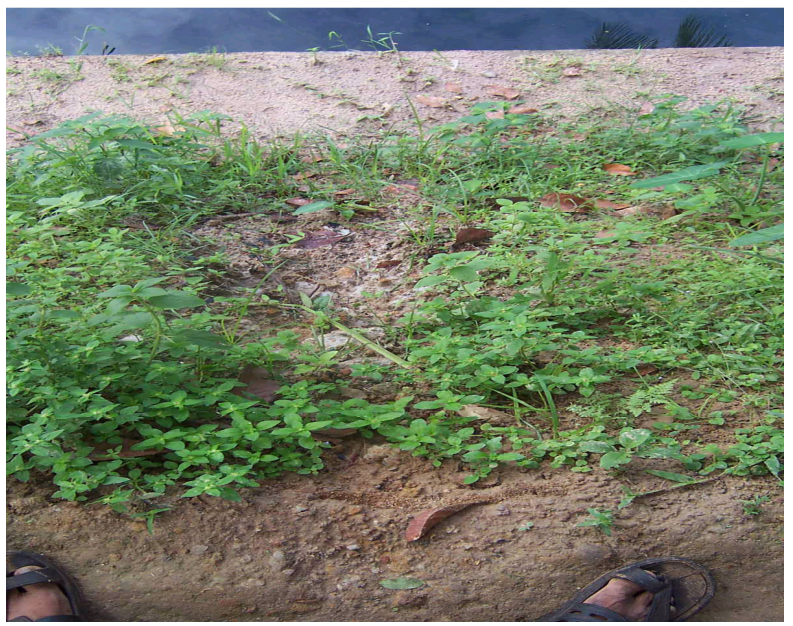

Fig. 11. CP- less density, non uniform vegetation with soil erosion, after 7 months.

\subsection{Nutrient losses}

High intensity rainfall in the tropics result in top soil erosion. Soil samples from the surface (top soil) were periodically collected from the field and tested in the laboratory for Nitrogen, Phosphorous, Potassium and organic carbon. In all the plots, it was seen that loss in NPK and organic carbon was higher in CP than in the plots treated with coir geotextiles. This is mainly due to the protective covering of the geotextiles. The net loss of nutrients in CGG, CG and CP are in the ratio 1: 1.3: 6.2 for Nitrogen, 1: 1.4: 3.5 for Phosphorous and 1: 1.4: 4.9 for Potassium. The loss in organic carbon in the three plots is in the ratio $1: 1.4: 2.8$. Difference in values in CGG and CG may be due to leaching of nutrients in CG during the initial stage. Figure 13 and Fig. 14 show variation

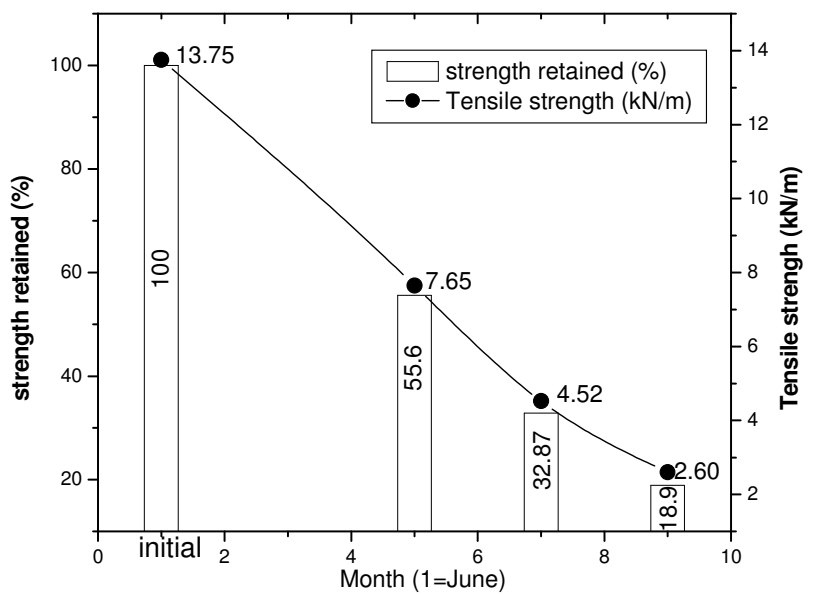

Fig. 12. Biodegradation of coir with time.

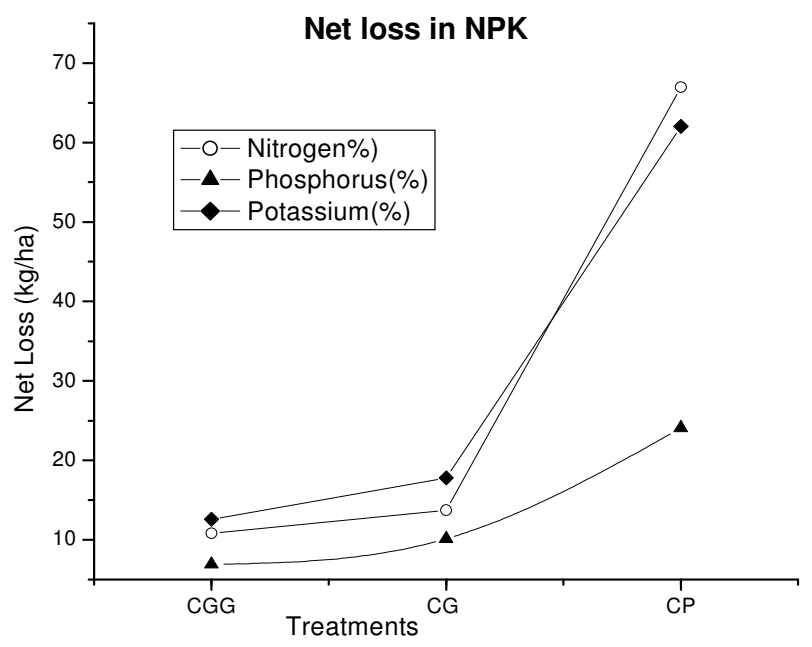

Fig. 13. Net loss in NPK.

in loss of NPK and organic carbon during the study period in the three treatments.

\subsection{Cost analysis}

India is the largest country (66\% of the world production) producing coir fibre, of which Kerala account for two-thirds of the production. According to FAO, out of the total annual global production of coconuts, only $10 \%$ of the coconut husk is used for fibre extraction which is estimated to be around $500 \mathrm{Gt} / \mathrm{year}$ of coir. Out of this only about $30 \%$ enters the world trade. Goshal and Som (1993), cited in: Kaniraj and Rao (1994) have presented an economical evaluation of the use of geotextiles from the Indian perspective. They compared the costs with synthetic geotextiles and conventional methods for typical geotechnical problems in four metropolitan cities of India. Even with synthetic geotextiles, it was found to be economical than the conventional 


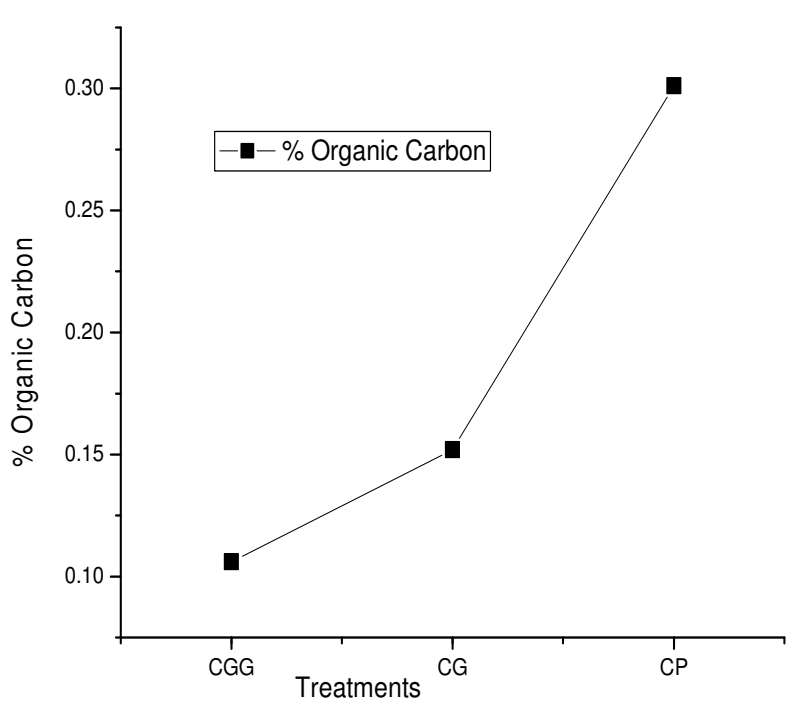

Fig. 14. Percentage loss in organic carbon in different treatments.

practices. Hence, in developing countries like India, if the efficiency of natural fibers can be effectively utilized, where it is abundantly available, this will prove to be a sustainable and affordable solution in many applications.

In this study, the cost of construction includes materials, transportation and labour charges. By the conventional method of slope protection using stone pitching is $2.50 \mathrm{euro} / \mathrm{m}^{2}$. However, by using coir geotextiles, the construction cost are less than $1 \mathrm{euro} / \mathrm{m}^{2}$ which includes the cost of geotextile and cost for clearing the site, laying geotextiles and planting grass on the surface. Moreover, unlike conventional structures, this structure provides a means for cultivation of fodder or other crops for the rural poor.

\section{Conclusions}

Field experiments, involving a local community in Kerala, have clearly demonstrated the effectiveness of coir geotextiles to stabilize banks of hydraulic structures and particularly the steeply sloping banks of a pond. The community was very enthusiastic about the effectiveness of the coir, particularly in combination with a local grass variety. The coir with grass appeared to be the most effective to prevent erosion, to retain moisture and nutrients and to facilitate grass growth. Moreover the slope with grass was productive in providing fodder. The degradation of the natural fibres over time did not result in any loss of effectiveness. On the contrary: the fibre contributed to the natural fertility of the soil after the vegetation cover was well established and the geotextile was no longer needed for bank stability. The relative cheapness of the material and the potential for producing and laying the matting with local labour makes the use of coir geotextiles a very attractive option for sustainable development scenarios in watershed management.

Acknowledgements. The authors express their sincere thanks to the watershed community and watershed committee members for their help throughout the experiment. The first author expresses sincere gratitude to the technical assistants who helped her to conduct the survey and to monitor the field data. Authors also express their gratitude to F. Preti (Referee) and the anonymous referee for their comments and suggestions that helped to make significant improvement to this paper.

Edited by: N. Romano

\section{References}

Abramson, L. W., Lee, T. S., Sharma, S., and Boyce, G.: Slope stability and stabilization methods, Wiley, New York, 1995.

Ahn, T. B. and Cho Yang, S. C.: Stabilization of soil slope using geosynthetic mulching mat, Technical note, Geotextiles and Geomembranes, 20, 135-146, 2002.

Anil, K. R.: Use of coir geotextiles for soil and water conservation at varying slopes, Technical Report to Coir Board, India, prepared by Kerala Agriculture University, Kerala, India, 2004.

Anil, K. R. and Sebastian, R.: Effect of coir geotextiles in Soil Conservation and slope land cultivation in varying land slopes with forest loam soil, in: Case histories of geosynthetics in infrastructure, edited by: Mathur G. N., Rao, G. V., and Chawla A. S., 73-77, CBIP publications, N.Delhi, India 2003.

ASTM D 4595-86.: Standard test method for tensile properties of geotextiles by the wide-width strip method, 1998.

Ayyar Ramanatha, T. S., Nair, R., and Nair, B. N. (Eds): Comprehensive Reference Book on Coir geotextiles, Centre for Development of Coir Technology, (C-DOCT), Trivandrum, 2002.

Balan, K.: Case Studies on the Civil Engineering Applications of Coir Geotextiles, in: Case histories of geosynthetics in infrastructure, edited by: Mathur, G. N., Rao, G. V., and Chawla, A. S., CBIP publications, N.Delhi, India, 172-176, 2003.

Balan, K. and Rao, V. G.: Durability of Coir Yarn for use in Geomeshes', proceedings of International seminar and technomeet on Environmental Geotechnology with Geosynthtics, ASEG/CBIP publications, New Delhi, 1996.

English, B.: Filters, Sorbents and geotextiles, in: Paper and composites from agro-based resources, Boca Raton, FL, CRC Press, Lewis Publishers, 403-425, 1997.

Bunch, R. and Lopez, G.: Soil recuperation in Central America: Sustaining Innovation after Intervention, Gatekeeper Series No. 55, International Institute for Environment and Development, London, 1999.

Ghoshal, A., and Som, N.: Geotextiles and geomembranes in India - State of usage and economic evaluation. Geotextiles and Geomembranes, 12, 193-213, 1993, in: Trends in the use of geotextiles in India, edited by: Kaniraj, S. R. and Rao, V. G., Geotextiles and Geomembranes, 13, 389-402, 1994.

Government of Kerala, (GoK): Soil Survey of Amachal Model watershed, Soil Survey Organisation, Department of Agriculture, Kerala, India, 2002. 
Johnson, N., Lilja, N., and Ashby, J.: Measuring the Impact of User Participation in Agricultural and Natural Resource Management Research, Agricultural Systems, 78, 287-306, 2003.

Lekha, K. R.: Field instrumentation and monitoring of soil erosion in coir geotextile stabilised slopes-A case study, Geotextiles and Geomembranes, 22, 399-413, 2004.

Mandal, J. N.: Geotextiles in India, Geotextiles and Geomembranes, 6, 253-274, 1987.

Ogbobe, O., Essien, K. S., and Adebayo, A.: A study of biodegradable geotextiles used for erosion control, Technical note, Geosynthetics Int., 5, 545-553, 1998.

Oosthuizen, D. and Kruger, D.: The use of Sisal Fibre as natural geotextile to control erosion, proceeding of the fifth international conference on geotextiles, geomembranes and related products, Singapore, 1994, in: Coir geotextiles- Emerging Trends, edited by: Rao, G. V. and Balan, K., The Kerala State Coir Corporation, Kerala, India, 2000.

Ranganathan, S. R.: Development and Potential of Jute geotextiles, Geotextiles and Geomembranes, 13, 421-433, 1994.

Rao, G. V., and Balan, K. (Eds.): Coir Geotextiles - Emerging trends, The Kerala State Coir Corporation, Kerala, India, 2000
Rickson, R. J.: Simulated vegetation and geotextiles, in: Slope stabilisation and erosion control: a bio-engineering approach, $\mathrm{E}$ and FN Spon, edited by: Morgan, R. P. C. and Rickson, R. J., London, ISBN 0419 156305, 1995.

Schurholz, H.: Use of woven coir geotextiles in Europe, Coir geotextiles conference, USA, 1991, in: Development of New Geosynthetic Products through Blending Of Natural Fibres, edited by: Banerjee P. K., in: Coir Geotextiles-Emerging trends, edited by: Rao, G. V. and Balan, K., The Kerala State Coir Corporation, Kerala, India, 2000.

Sutherland, R. A., Menard, T., and Perry, J. L., The influence of rolled erosion control systems on soil moisture content and biomass production: Part II. A greenhouse experiment, Land Degrad. Dev., 9, 217-231, 1998.

Thomson, J. C. and Ingold, T. S.: Use of Jute fabrics in erosion control, Report to the Jute Market promotion Project, International jute Organisation, International trade centre, UNCTAD/GATT, GENEVA, 1986.

Ziegler, A. D., Sutherland, A., and Tran, L. T.: Influence of Rolled Erosion Control systems on temporal rainspalsh response- A laboratory rainfall simulation experiment, Land Degrad. Dev., 8, 139-157, 1997. 